\title{
Dysregulation of microRNAs in breast cancer and their potential role as prognostic and predictive biomarkers in patient management
}

\author{
Eleni van Schooneveld ${ }^{1 *}$, Hans Wildiers ${ }^{1}$, Ignace Vergote ${ }^{1}$, Peter B Vermeulen ${ }^{2}$, Luc Y Dirix ${ }^{2}$ and Steven J Van Laere ${ }^{1,2}$
}

\begin{abstract}
MicroRNAs (miRNAs) are an emerging class of gene expression modulators with relevant roles in several biological processes, including cell differentiation, development, apoptosis, and regulation of the cell cycle. Deregulation of those tiny RNA molecules has been described frequently as a major determinant for the initiation and progression of diseases, including cancer. Not only miRNAs but also the enzymes responsible for miRNA processing could be deregulated in cancer. In this review, we address the role of miRNAs in the pathogenesis of breast cancer, since there are oncogenic, tumor-suppressive, and metastatic-influencing miRNAs. Additionally, the different detection platforms and normalization strategies for miRNAs will be discussed. The major part of this review, however, will focus on the capability of miRNAs to act as diagnostic, predictive, or prognostic biomarkers. We will give an overview of their potential to correlate with response to or benefit from a given treatment and we will consider their ability to give information on prognosis in breast cancer. We will focus on miRNAs validated by more than one study or verified in independent cohorts or where results rely on preclinical as well as clinical evidence. As such, we will discuss their potential use in the personalized management of breast cancer.
\end{abstract}

\section{Introduction}

\section{Breast cancer and breast cancer heterogeneity}

Breast cancer is the most frequent carcinoma and second most common cause of cancer-related mortality in women [1]. Its heterogeneous character is reflected in the classification into four intrinsic subtypes (luminal A, luminal B, basal-like, and $\mathrm{ErbB}^{+}$), a normal-like group, and a new subtype, referred to as claudin-low. Histologically, breast cancer can be divided into in situ and invasive carcinoma, both of which can be further subdivided into ductal and lobular. Stratification by integrative clustering is based on genomic and transcriptomic data [2]. Curtis and colleagues [2] revealed new biological subgroups as integrative clusters, characterized by welldefined copy number alterations, gene expression, and distinct clinical outcomes.

\footnotetext{
*Correspondence: eleni.vanschooneveld@gmail.com

'Department of Oncology, University Hospitals Leuven and Catholic

University Leuven, Herestraat 49, Leuven B-3000, Belgium

Full list of author information is available at the end of the article
}

\section{MicroRNAs}

MicroRNAs (miRNAs) are a group of small non-coding RNAs able to regulate gene expression at the posttranscriptional level by binding to the $3^{\prime}$ untranslated region (UTR) of target mRNAs. This leads to cleavage of the target mRNA by the Ago2 ribonuclease in the RNAinduced silencing complex (RISC) or inhibition of translation [3]. Alternatively, miRNAs can exert their effect by modulating the relationship between effector and target mRNAs rather than acting as regulators of particular mRNAs [4]. Deregulation of miRNA expression and potential altered gene expression may contribute to the development of cancerous phenotypes [5]. Several studies showed a differential miRNA expression profile in cancer as compared with normal, and a global miRNA downregulation was a common trait of human malignancies $[6,7]$.

\section{Materials and methods}

Relevant published articles were searched on PubMed databases from 2001 to present by using the following

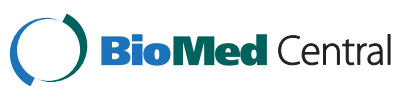

(C) 2015 van Schooneveld et al.; licensee BioMed Central. This is an Open Access article distributed under the terms of the Creative Commons Attribution License (http://creativecommons.org/licenses/by/4.0), which permits unrestricted use, distribution, and reproduction in any medium, provided the original work is properly credited. The Creative Commons Public Domain Dedication waiver (http://creativecommons.org/publicdomain/zero/1.0/) applies to the data made available in this article, unless otherwise stated. 
search criteria to retrieve articles and abstracts: (microRNA* or miR*) AND (breast cancer); depending on the chapter discussed in the review, we complemented this with AND (diagnostic OR prognostic OR predictive).

We focused on recent publications or findings validated by several independent studies. Studies were considered eligible on the basis of the following inclusion criteria: (i) miRNAs were evaluated in breast cancer cells or samples (blood or tissue) derived from patients with breast cancer, including publically available breast cancer cohorts; (ii) the relationship between the studied miRNAs and breast cancer biology was investigated, or (iii) the relationship between miRNAs and outcome or therapy response in breast cancer was examined. Articles were excluded if they met one of the following criteria: (i) published articles were retracted articles or comments; (ii) lack of key information on breast cancer biology, prognosis, or prediction of therapy response; and (iii) manuscripts reported on cancer types other than breast cancer.

\section{MicroRNAs and breast cancer \\ The role of microRNAs in breast cancer biology and metastasis}

In cancer, miRNAs play a role in oncogenesis, metastasis, and resistance to various therapies and can be classified as oncogenes (oncomirs) or tumor-suppressor genes [8-10]. Additionally, both pro-metastatic ('metastamiRs') and metastasis-suppressor miRNAs can be identified [11,12].

Many miRNA genes are located in genomic regions involved in chromosomal alterations. Chromosomal regions encompassing oncogenic miRNAs may be amplified, resulting in increased expression of the oncomir. Tumor-suppressive miRNAs could reside in fragile sites characterized by deletions or mutations, leading to reduced levels of these miRNAs $[13,14]$. An overview of the most prominent miRNAs involved in the pathogenesis of breast cancer is depicted in Tables 1 and 2.

\section{Oncogenic microRNAs and 'metastamiRs'}

Examples of breast oncomirs are miR-10b, miR-21, miR155, miR-373, and miR-520c. (See Table 1 and list of abbreviations for miRNA targets.) OncomiRs exert their oncogenic activity by targeting tumor-suppressor genes and activating oncogenic transcription factors $[8,15]$.

MiR-10b targets HOXD10, thereby promoting cell migration and invasion $[8,16,17]$. miR-21 has been reported to be associated with invasive and metastatic breast cancer [18] and regulates epithelial-to-mesenchymal transition (EMT) and HIF1A in breast cancer stem cell-like cells [19]. It also inhibits various tumor-suppressor proteins [20-22]. MiR-155 suppresses SOCS1 both in vivo and in vitro [23], and upregulation results in proliferation of MCF7 cells [24]. FOXO3 was identified as another miR155 target, whose inhibition leads to enhanced cell survival and tumor growth [25]. The expression of miR-373 and $-520 \mathrm{c}$, which target CD44, is associated with metastasis, invasion, and migration [26,27].

\section{Tumor-suppressive and metastasis-suppressive microRNAs}

Tumor-suppressor miRNAs exhibit a lower expression in cancer cells and suppress oncogene expression, thereby controlling cellular differentiation [28]. In regard to the global downregulation of miRNAs in cancer, it is worth mentioning that the majority of miRNAs have a tumorsuppressive function, some of which exhibit anti-metastatic properties as well. (See Table 2 and list of abbreviations for miRNA targets).

MiR-125b, which targets erythropoietin (EPO) and its receptor (EPOR) as well as ERBB2, is found to be one of the most downregulated miRNAs in breast cancer [29-31].

Table 1 List of major oncogenic microRNAs in breast cancer

\begin{tabular}{|c|c|c|c|c|}
\hline miRNA & Target & Function & Number of samples ${ }^{a}$ & Reference \\
\hline miR-10b & HOXD10 & Promotes cell migration, invasion and metastasis & $n=23$ & {$[8,16,17]$} \\
\hline \multirow[t]{3}{*}{$\operatorname{miR}-21$} & PDCD4, HIF1A & Promotes invasion, metastasis, migration and EMT & Cell culture study & {$[18,19,22]$} \\
\hline & TPM1, PTEN, PDCD4 & Promotes invasion & $\mathrm{n}=17$ & {$[20]$} \\
\hline & TIMP3 & Promotes invasion & $n=32$ & [21] \\
\hline \multirow[t]{3}{*}{ miR-155 } & SOCS1 & Promotes cell growth and proliferation & $n=15$ & [23] \\
\hline & TP53INP1 & Promotes proliferation & Cell culture study & [24] \\
\hline & $\mathrm{FOXO3}$ & Promotes proliferation and survival & $n=115$ & [25] \\
\hline \multirow[t]{2}{*}{ miR-373 } & CD44 & Promotes cell migration and invasion & $\mathrm{n}=11$ & {$[26]$} \\
\hline & & Promotes invasion and metastasis & Cell culture study & {$[27]$} \\
\hline miR-520c & CD44 & Promotes cell migration, invasion and metastasis & $n=11$ & {$[26]$} \\
\hline
\end{tabular}

MetastamiRs are indicated in bold. ${ }^{a}$ When applying more than one reference, we focused on the study with the most relevant number of investigated patient samples. The other studies serve as validation and confirm the results. EMT, epithelial-to-mesenchymal transition; FOXO3, forkhead box protein O3; HIF1A, hypoxia-inducible factor-1a; HOXD10, homeobox D10; miRNA, microRNA; PDCD4, programmed cell death protein 4; PTEN, phosphatase and tensin homolog; SOCS1, suppressor of cytokine signaling 1; TIMP3, metalloproteinase inhibitor 3; TM1, tropomyosine 1; TP53INP, tumor protein p53 inducible nuclear protein. 
Table 2 List of major tumor suppressive microRNAs in breast cancer

\begin{tabular}{|c|c|c|c|c|}
\hline miRNA & Target & Function & Number of samples ${ }^{a}$ & Reference \\
\hline \multirow[t]{3}{*}{ miR-125b } & EPO, EPOR & Inhibits cell proliferation and differentiation & $n=42$ & [29] \\
\hline & ENPEP, CK2-a,CCNJ, MEGF9 & Inhibits cell proliferation & $n=25$ & [30] \\
\hline & ERBB2 & Inhibits migration and invasion & Cell line study & [31] \\
\hline miR-205 & HMGB3 & Suppresses proliferation and invasion & $n=20$ & {$[32,33]$} \\
\hline miR-17-92 & Mekk2 & Promotes NK cell antitumoral activity and reduces metastasis & $n=20$ & {$[34,35]$} \\
\hline miR-206 & Cyclin D2, Cx43 & Reduces migration, invasion and metastasis & $n=128$ & {$[36,37]$} \\
\hline miR-200 & ZEB1/2, SNAl1/2 & Reduces tumor growth, metastasis and EMT & $n=70$ & [38-40] \\
\hline miR-146b & NFkB, STAT3 & Reduces survival and metastasis & $n=91$ & {$[41,42]$} \\
\hline \multirow[t]{2}{*}{ miR-126 } & IGFBP2, MERTK,PITPNC1 & Reduces metastasis and angiogenesis & $n=117, n=295$ & [43] \\
\hline & No specific targets listed & Reduces tumorigenesis and metastasis & Cell line study & [44] \\
\hline $\operatorname{miR}-335$ & SOX4, TNC & Suppresses metastasis and migration & $n=20$ & {$[44,45]$} \\
\hline \multirow[t]{3}{*}{ miR-31 } & RhoA & $\begin{array}{l}\text { Inhibits several steps of the invasion-metastasis } \\
\text { cascade in breast cancer }\end{array}$ & $n=54$ & [46] \\
\hline & WAVE3, RhoA & Reduces cancer progression and metastasis & Cell line study & [47] \\
\hline & WAVE3 & Reduces cancer progression and metastasis & $n=19$ & [48] \\
\hline
\end{tabular}

Metastasis-suppressive miRs are indicated in bold. ${ }^{a}$ When applying more than one reference, we focused on the study with the most relevant number of investigated patient samples. The other studies serve as validation and confirm the results. CCNJ, cyclin J; CK2-a, casein kinase 2-alpha; Cx43, connexin 43; ENPEP, glutamylaminopeptidase or aminopeptidase A; EPO, erythropoietin; EPOR, erythropoietin receptor; ERBB2, Receptor tyrosine-protein kinase erbB-2 (human epidermal growth factor receptor 2); HMGB3, high-mobility group box 3 gene; IGFBP2, insulin-like growth factor-binding protein 2; MEGF9, multiple EGF-like domains 9; Mekk2, mitogen-activated protein kinase kinase kinase 2; MERTK, c-Mer tyrosine kinase; miRNA, microRNA; NFkB, nuclear factor kappa B; NK, natural killer; PITPNC1, phosphatidylinositol transfer protein, cytoplasmic 1; RhoA, Ras homolog gene family; SNAI1/2, snail family zinc finger 1/2; SOX4, SRY-related HMG-box 4; STAT3, signal transducer and activator of transcription 3; TNC, tenascin C; WAVE3, WAS protein family, member 3; ZEB1/2, zinc finger E-box binding homeobox 1/2.

MiR-205 regulates HMGB3 and its ectopic expression significantly inhibits cell proliferation and promotes apoptosis in breast cancer [32,33]. Jiang and colleagues [34] revealed how expression of the miR-17-92 cluster in triple-negative breast cancer (TNBC) was associated with significantly reduced metastasis [35]. miR-206 inhibits cell proliferation, migration, and invasion by targeting cyclin D2 and Cx43 [36,37].

Certain tumor-suppressive miRNAs have an inhibitory role in the metastasis cascade. For example, the miR-200 family regulates EMT via E-cadherin expression by targeting several EMT inducers [38-40]. MiR-146b inhibits nuclear factor kappa B (NF-kB)-dependent interleukin (IL)-6 expression, which is associated with impaired survival and metastasis of cancer cells [41,42]. Decreased expression of miR-126 was seen in a variety of human cancers, and restoration of expression reduced metastatic endothelial recruitment and angiogenesis [43,44]. MiR-335 is known to target several metastasis-associated genes (for example, SOX4 and TNC) $[44,45]$. Finally, independent studies have reported the pleiotropic actions of miR-31 on breast cancer metastasis and its ability to suppress multiple steps of the invasion-metastasis cascade, by targeting RhoA and WAVE3 [46-48].

\section{Context-dependent microRNAs}

The action of certain miRNAs is dependent upon cellular or environmental context and results in both tumorsuppressive and -promoting roles $[17,49]$. This could in part explain possible inconsistent outcomes from distinct miRNA-examining studies.

As described above, miR-146 exerts its tumor-suppressive action through negative regulation of NF- $\mathrm{BB}$ signaling [41]. However, an additional target is the pro-apoptotic DNA repair enzyme BRCA1 [50]. MiR-29 stimulates metastasis and EMT by suppressing the cell-adhesion molecule peroxidasin homologue but is also capable of restraining cancer progression by targeting proliferationinducing oncogenes, suppressing DNA methylation of tumor-suppressor genes, and increasing chemosensitivity [51]. Although most data support an oncogenic function for miR-373 and -520c [26,27], a recent study reported this miR-family as a tumor suppressor in estrogen receptor (ER)-negative breast cancer [52].

\section{MicroRNA detection and normalization}

\section{MicroRNA detection and genome-wide approaches}

Many hybridization-based miRNA detection platforms are being described. Though low-throughput, the most standardized method for miRNA analysis is Northern blotting [53]. High-throughput methods for miRNA detection are the oligonucleotide miRNA microarray and real-time reverse transcription-polymerase chain reaction (RT-PCR). MiRNA microarrays are capable of analyzing hundreds of miRNAs (genome wide) in a large number of samples. Integration of the obtained miRNA data with mRNA expression data is useful to discover new miRNA-gene interactions [54]. RT-PCR is another 
sensitive technique used for assessment of miRNA expression or validation of data obtained from other detection platforms [55]. Other detection techniques include bead-based flow cytometry [6] and in situ hybridization [56]. The limitation of the above-mentioned platforms is their restriction to known miRNA structures. Nextgeneration sequencing technologies provide new approaches for discovery of new and confirmation of known miRNAs [57,58]. An overview of the most prominent miRNA detection methods is shown in Table 3.

\section{MicroRNA normalization}

Good normalization procedures for miRNA expression are still lacking. A normalization strategy for miRNA quantitative RT-PCR (qRT-PCR) is the use of endogenous controls, like reference miRNAs (for example, miR-16) or other small non-coding RNAs (for example, small nuclear and nucleolar RNA). However, it is recommended to use reference molecules belonging to the same RNA class since they possess the same physicochemical properties [59]. This is why miR-16 would be preferable over the use of small nucleolar and nuclear RNAs and was used in our study to normalize quantitative PCR data obtained from miRNA expression analysis in blood [60]. Also, the quantification accuracy increases by use of more than one reference gene [59]. Another example of a potential reliable reference gene is miR-484, whose referencegene utility may be enhanced by averaging with other potential breast cancer housekeeping miRNAs (for example, miR-330-3p, -4327, and -1271) [4]. Other normalization strategies for miRNA expression include the mean expression value strategy, as proposed by Mestdagh and colleagues [61].

\section{MicroRNAs as diagnostic, predictive, and prognostic biomarkers}

The ideal biomarker should be easily accessible, sensitive enough to detect all tumors, and specific and therefore not detectable in healthy individuals. Because of their high tissue-specificity, great stability, and aberrant expression in different tumor types, miRNAs are thought

Table 3 The most prominent microRNA detection methods

\begin{tabular}{|c|c|c|c|c|}
\hline Detection method & Throughput & Sensitivity & Specificity & Reference \\
\hline Northern blotting & Low & Low & High & [53] \\
\hline Microarray & High & Low & Low & [54] \\
\hline $\begin{array}{l}\text { Bead-based } \\
\text { flow cytometry }\end{array}$ & High & Medium & High & {$[6]$} \\
\hline qRT-PCR & High & High & High & {$[55]$} \\
\hline In situ hybridization & Low & Low & Low & {$[56]$} \\
\hline $\begin{array}{l}\text { Next-generation } \\
\text { sequencing }\end{array}$ & High & High & High & {$[57,58]$} \\
\hline
\end{tabular}

qRT-PCR, quantitative real-time polymerase chain reaction. of as specific biomarkers with diagnostic, predictive, and prognostic potential (Figure 1).

\section{MicroRNAs as diagnostic biomarkers for breast cancer heterogeneity \\ Early diagnosis of breast cancer}

Early diagnosis is of utmost importance to reduce the mortality rate in cancer. Therefore, the search for new diagnostic biomarkers remains a persisting quest. The main examined diagnostic miRNA signatures will be discussed, with a focus on those miRNAs validated by more than one study or verified in different cohorts or both. (For a detailed overview of the individual miRNAs, see Table 4).

In a recent study, a signature of nine circulating miRNAs was capable of discriminating between early-stage breast cancer and healthy controls [62]. A meta-analysis concerning miR-155 showed highly sensitive and specific diagnostic accuracy [63]. By comparing miRNA profiles between serum samples from breast cancer patients and healthy volunteers, Chan and colleagues [64] identified four miRNAs as significant diagnostic markers. Cuk and colleagues [65] found another four upregulated miRNAs in plasma of patients with breast cancer, capable of detecting stage I or II breast cancer, making them attractive candidates for early breast cancer detection. Another study reported three upregulated miRNAs and one downregulated miRNA in patients with breast cancer compared with normal controls [66]. A prospective study identified three significantly overexpressed serum miRNAs in women who eventually developed breast cancer (cases) compared with breast cancer-free controls [67]. This study introduces a new perspective on the miRNA function by describing their potential to predict increased risk of developing breast cancer.

\section{Breast cancer molecular subtypes and microRNAs}

We have shown that microRNA expression profiles are able to recapitulate the molecular breast cancer subtypes by using mRNA profiling [60,68]. Molecular miRNA signatures which distinguish between different breast cancer subtypes were described for the first time (to the best of our knowledge) by Blenkiron and colleagues [69] and reviewed by Serpico and colleagues [70]. The commonly found molecular subtype-related miRNAs are presented in Table 5.

Blenkiron and colleagues [69] profiled 309 miRNAs in 93 breast tumors with different molecular subtypes. The differential miRNA expression resulted in a correct classification of basal versus luminal subtypes. An identified 31-miRNA signature was able to distinguish the different breast cancer subtypes. de Rinaldis and colleagues [71] found consistent results by revealing a 46-miRNA signature able to differentiate between breast cancer subtypes 


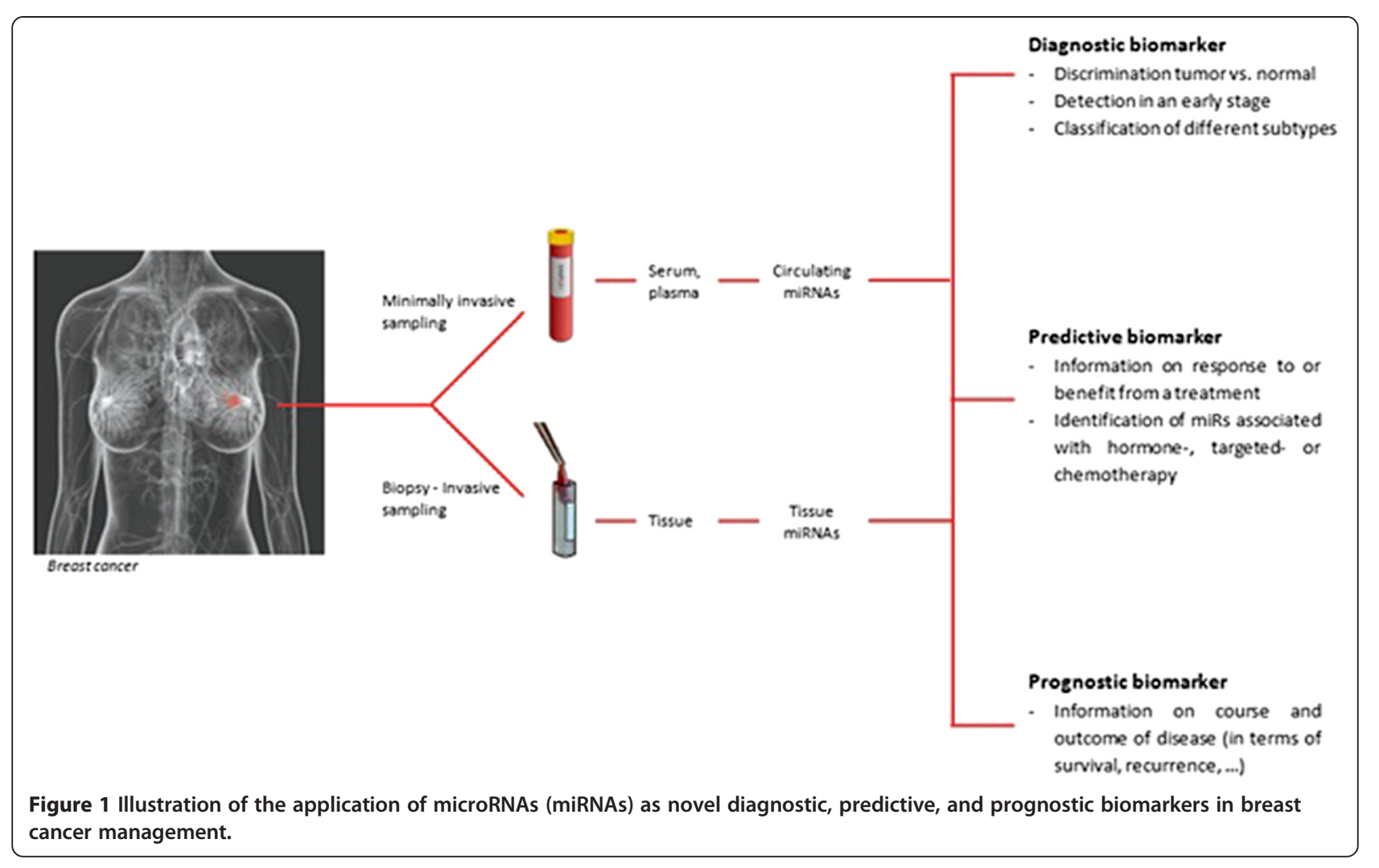

$(\mathrm{n}=173)$. A substantial degree of consistency was also observed by Dvigne and colleagues [4], and the common miRNA signatures for molecular breast cancer subtypes are listed in Table 5.

In another study, 453 miRNAs in 29 early-stage breast cancer tumors were profiled, identifying signatures that accurately predict ER, progesterone receptor (PR), and HER2 status (Table 6) [72]. miR-342 showed the highest expression in ER-positive and HER2/neu-positive luminal B tumors, which was verified in recent studies $[73,74]$, and showed a decreased expression in TNBC. MiR-520 g was downregulated in ER- and PR-positive tumors.

\section{Breast cancer histological subtypes and microRNAs}

Little is known about the correlation of histological subtypes and specific miRNA expression patterns and it is definitely worthwhile to further investigate this relation in the future.

Volinia and colleagues [75] found a nine-miR invasiveness signature by profiling miRNAs in ductal carcinoma in situ and invasive ductal carcinoma (IDC). Giricz and colleagues [76] revealed six differentially expressed miRNAs during progression from lobular carcinoma in situ to invasive lobular carcinoma. Van der Auwera and colleagues [77] showed a differential expression of $13 \mathrm{miR}$ NAs in inflammatory breast cancer (IBC) versus non-IBC.
Another study examined the miRNA expression profile in IBC and found five miRNAs able to accurately classify between IBC and non-IBC [78].

\section{Predictive microRNAs}

Predictors help to individualize therapy and diagnosis of breast cancer, correlate with response to a given treatment, and determine the treatment benefit. Recently, several miRNAs have been described to serve as putative therapeutic targets. (See Table 7 for described miRNAs and Additional file 1: Table SI 1 for a more extensive overview of predictive miRNAs).

\section{MicroRNAs associated with hormone therapies}

MiRNAs appear to be involved in the process of endocrine resistance [79], and research has been conducted to identify miRNAs associated with clinical benefit of hormone therapies.

miR-375 miR-375 demonstrated its sensitizing effect on tamoxifen response via direct targeting of metadherin (MTDH). Loss of MTDH restored sensitivity to tamoxifen and correlated with disease-free survival (DFS) in tamoxifen-treated patients [80].

miR-342 He and colleagues [74] found that miR-342 expression positively correlates with ER $\alpha$ expression and 
Table 4 List of major diagnostic microRNA signatures for the early diagnosis of breast cancer

\begin{tabular}{|c|c|c|c|c|c|}
\hline miR signature & Expression (BC vs normal) & Sample type & $\begin{array}{l}\text { Number of samples: } \\
\text { BC (normal) }\end{array}$ & Validation & Reference \\
\hline miR-15a & Upregulated & Serum & $n=48(24)$ & $n=60(51)$ & [62] \\
\hline miR-18a & Upregulated & Serum & $\mathrm{n}=48(24)$ & $n=60(51)$ & [62] \\
\hline miR-107 & Upregulated & Serum & $n=48(24)$ & $n=60(51)$ & [62] \\
\hline miR-425 & Upregulated & Serum & $n=48(24)$ & $n=60(51)$ & [62] \\
\hline miR-133a & Downregulated & Serum & $n=48(24)$ & $\mathrm{n}=60(51)$ & [62] \\
\hline miR-139-5p & Downregulated & Serum & $n=48(24)$ & $\mathrm{n}=60(51)$ & [62] \\
\hline miR-143 & Downregulated & Serum & $\mathrm{n}=48(24)$ & $\mathrm{n}=60(51)$ & [62] \\
\hline miR-145 & Downregulated & Serum & $n=48(24)$ & $\mathrm{n}=60(51)$ & [62] \\
\hline miR-365 & Downregulated & Serum & $n=48(24)$ & $n=60(51)$ & [62] \\
\hline miR-155 & Upregulated & Serum & $\mathrm{n}=184(75)$ & $\begin{array}{l}\text { Meta-analysis (inclusion } \\
\text { of } 3 \text { studies) }\end{array}$ & [63] \\
\hline miR-1 & Upregulated & Serum & $n=32(22)$ & $\mathrm{n}=132(101)$ & [64] \\
\hline miR-133a & Upregulated & Serum & $\mathrm{n}=32(22)$ & $n=132(101)$ & [64] \\
\hline miR-133b & Upregulated & Serum & $n=32(22)$ & $n=132(101)$ & [64] \\
\hline miR-92a & Upregulated & Serum & $\mathrm{n}=32(22)$ & $n=132(101)$ & [64] \\
\hline miR-148b & Upregulated & Plasma & $\mathrm{n}=127(80)$ & $\mathrm{n}=207(80)$ & [65] \\
\hline miR-376c & Upregulated & Plasma & $\mathrm{n}=127(80)$ & $\mathrm{n}=207(80)$ & [65] \\
\hline miR-409-3p & Upregulated & Plasma & $\mathrm{n}=127(80)$ & $\mathrm{n}=207(80)$ & [65] \\
\hline miR-801 & Upregulated & Plasma & $\mathrm{n}=127(80)$ & $\mathrm{n}=207(80)$ & [65] \\
\hline miR-16 & Upregulated & Plasma \& tissue & $\mathrm{n}=15$ & $\mathrm{n}=170(100)^{\mathrm{a}}$ & [66] \\
\hline miR-21 & Upregulated & Plasma \& tissue & $n=15(15)$ & $n=170(100)^{a}$ & [66] \\
\hline miR-451 & Upregulated & Plasma \& tissue & $n=15(15)$ & $\mathrm{n}=170(100)^{\mathrm{a}}$ & [66] \\
\hline miR-145 & Downregulated & Plasma \& tissue & $\mathrm{n}=15$ & $\mathrm{n}=170(100)^{\mathrm{a}}$ & [66] \\
\hline miR-18a & Overexpressed in cases compared to controls ${ }^{b}$ & Serum & $\mathrm{n}=205(205)$ & $n=5(5)$ & [67] \\
\hline miR-181a & Overexpressed in cases compared to controls ${ }^{b}$ & Serum & $n=205(205)$ & $\mathrm{n}=5(5)$ & [67] \\
\hline miR-222 & Overexpressed in cases compared to controls ${ }^{b}$ & Serum & $n=205(205)$ & $\mathrm{n}=5(5)$ & [67] \\
\hline
\end{tabular}

Common microRNAs (miRNAs) are indicated in bold. ${ }^{a}$ miRs only detected in plasma, not in tissue. ${ }^{b}$ Cases, women who developed breast cancer (BC); controls, women who stayed BC-free.

that introducing miR-342 into estrogen-dependent breast cancer cell lines enhanced sensitivity to tamoxifen-induced apoptosis. Cittelly and colleagues [81] verified these findings and reported miR-342 downregulation to be associated with tamoxifen resistance.

Table 5 Common subtype-specific microRNAs found by meta-analysis of three independent studies

\begin{tabular}{llll}
\hline Luminal A & Basal & HER2 & Normal-like \\
\hline let-7c & miR-18a & miR-142-3p & miR-145 \\
miR-10a & miR-135b & miR-150 & miR-99a \\
let-7f & miR-93 & & miR-100 \\
& miR-155 & & miR-130a \\
\hline
\end{tabular}

Common subtype-specific microRNAs (miRNAs) ${ }^{\text {a }}$ derived from analysis by Dvinge et al. [4] (2013), Blenkiron et al. [69] (2007), and de Rinaldis et al. [71] (2013). ${ }^{a}$ No common miRNAs for the luminal B subtype could be found.
miR-221/222 The miR-221/222 cluster is an inhibitor of ER $\alpha$ and is being associated with tamoxifen resistance in breast cancer cells [82-84]. This miRNA cluster has also been involved in resistance to fulvestrant, a selective ER downregulator [85].

Let-7f Aromatase inhibitors are used in endocrine therapy since they decrease estrogen production by blocking the aromatase gene CYP19A1, a direct target of let-7 $\mathrm{f}$. MiRNA expression profiling before and after treatment with letrozole showed an increase in let-7f in preclinical as well as clinical settings [86].

\section{MicroRNAs associated with targeted therapies}

miR-210 Jung and colleagues [87] examined the plasma miR-210 expression level in patients with HER2 ${ }^{+}$breast cancer before (that is, baseline expression) and after 
Table 6 MicroRNA signatures for estrogen receptor, progesterone receptor, and HER2/neu receptor status in breast cancer

\begin{tabular}{lll}
\hline miRNA & $\begin{array}{l}\text { Median accuracy, } \\
\text { percentage }\end{array}$ & $\begin{array}{l}\text { Increased miRNA expression } \\
\text { gives higher probability of: }\end{array}$ \\
\hline ER status & 83.3 & ER (+) status \\
miR-342 & 100 & ER (-) status \\
miR-299-3p & 100 & ER (+) status \\
miR-217 & 100 & ER (-) status \\
miR-190 & 100 & ER (-) status \\
miR-135b & 100 & ER (+) status \\
miR-218 & & \\
$\begin{array}{l}\text { PR status } \\
\text { miR-520 g }\end{array}$ & 83.3 & PR (-) status \\
miR-377 & 83.3 & PR (+) status \\
miR-527-518a & 100 & PR (-) status \\
miR-520f-520c & 100 & PR (+) status \\
HER2/neu status & & \\
miR-520d & 100 & HER2/neu (+) status \\
miR-181c & 100 & HER2/neu (-) status \\
miR-302c & 100 & Weak response \\
miR-376b & 100 & HER2/neu (+) status \\
miR-30e-3p & 100 & Weak response \\
\hline
\end{tabular}

Lowery et al. [72] (2009). ER, estrogen receptor; miRNA, microRNA; PR, progesterone receptor. neoadjuvant chemotherapy (NCT) that included trastuzumab. MiR-210 was the only miRNA with a significant upregulated baseline expression in the residual disease group before treatment. Therefore, high miR-210 baseline expression was associated with resistance to trastuzumab-included chemotherapy. Results were validated by comparing miR-210 expression in trastuzumabsensitive and -resistant breast cancer cells and in an independent set of pre- and post-operative plasma samples. A significantly higher miR-210 level was found in the trastuzumab-resistant cells and in the independent patient cohort before surgery.

\section{MicroRNAs associated with response to chemotherapeutic agents}

Drug sensitivity varies with each patient, making predictors of benefit or resistance toward proposed chemotherapeutic agents essential. In this way, the proportion of patients with a beneficial treatment would increase and toxicity of ineffective treatments would be avoided.

miR-125b Zhou and colleagues [88] reported resistance to various chemotherapies induced by miR-125b targeted repression of Bak1 (BCL2 antagonist killer 1), which was verified by the clinical findings of Wang and colleagues [89], who reported higher miR-125b expression in nonresponsive patients after admission of 5-fluorouracil. Climent and colleagues [90] reported miR-125b deletion

Table 7 Predictive microRNAs - microRNAs involved in response (sensitivity/resistance) to conventional breast cancer therapeutic strategies

\begin{tabular}{|c|c|c|c|c|c|c|}
\hline Therapy & Generic name & miRNA & Role in response $^{a}$ & Evidence & Number of patients or type of cells & Reference \\
\hline \multicolumn{7}{|c|}{ Hormone therapy } \\
\hline \multirow[t]{4}{*}{ SERM } & Tamoxifen & miR-375 & Sensitivity & Preclinical/clinical & 2 BC datasets & {$[80]$} \\
\hline & & miR-342 & Sensitivity & Preclinical & MCF-7 & [74] \\
\hline & & & Sensitivity & Clinical & $n=791$ & [81] \\
\hline & & miR-221/222 & Resistance & Preclinical & MCF-7, T47D, MM-468 & {$[82-84]$} \\
\hline SERD & Fulvestrant & miR-221/222 & Resistance & Preclinical & MCF-7 & {$[85]$} \\
\hline $\mathrm{Al}$ & Letrozole & let-7f & Sensitivity & Preclinical/clinical & $n=23$ & {$[86]$} \\
\hline \multicolumn{7}{|l|}{ Targeted therapy } \\
\hline Monoclonal $A B$ & Trastuzumab & miR-210 & Resistance & Preclinical/clinical & $n=43$ & {$[87]$} \\
\hline \multicolumn{7}{|l|}{ Chemotherapy } \\
\hline & FEC & miR-125b & Resistance & Preclinical/clinical & $n=56$ & [89] \\
\hline & & & Resistance & Preclinical & MM-435, SKBR3 & {$[88]$} \\
\hline & & & Resistance & Clinical & $n=185$ & {$[90]$} \\
\hline & Taxol/doxo & miR-30c & Sensitivity & Preclinical & T47D, MCF-7, MM-231 & {$[91,92]$} \\
\hline & Taxol & $\operatorname{miR}-21$ & Resistance & Preclinical & MM-468 & {$[9,93]$} \\
\hline \multicolumn{7}{|l|}{ Radiotherapy } \\
\hline & Radiotherapy & miR-34a & Sensitivity & Preclinical & T47D, MCF-7, MM-231 & {$[95,96]$} \\
\hline
\end{tabular}

a MicroRNA (miRNA) overexpression leads to an increase in resistance or sensitivity to the mentioned therapy (referred to as 'resistance' or 'sensitivity', respectively). $\mathrm{AB}$, antibody; $\mathrm{Al}$, aromatase inhibitor; $\mathrm{BC}$, breast cancer; Doxo, doxorubicin; $\mathrm{FEC}$, fluorouracil, epirubucin and cyclophosphamide; SERD, selective estrogen receptor downregulator; SERM, selective estrogen receptor modulator; Taxol, paclitaxel. 
on chromosome 11q to be correlated with benefit of anthracycline-based chemotherapy and low recurrence rate in patients with lymph node-negative breast cancer.

miR-30c Bockhorn and colleagues [91] described how increased levels of miR-30c sensitized the drug response of breast cancer cell lines to paclitaxel and doxorubicin, and this was also seen in the preclinical model by Fang and colleagues [92].

miR-21 Mei and colleagues [93] reported miR-21 upregulation to be associated with taxol resistance in breast cancer cells. These results were validated in a recent study, in which miR-21 upregulation resulted in an increase of the anti-apoptosis protein BCL-2 and chemoresistance in breast cancer cells [9]. The increase of BCL-2 expression was induced by direct targeting by miR-21, which was able to unconventionally upregulate the expression of its direct target by binding to its 3' UTR [94].

\section{MicroRNAs associated with radiotherapy}

miR-34a Low levels of miR-34a rendered breast cancer cells more resistant to radiotherapy [95]. These findings were verified by Stankevicins and colleagues [96], who postulated that miR-34a was involved in breast cell responses to low-dose $\mathrm{X}$ radiation. Moreover, miR-34a was found to be upregulated by p53 in response to radiation in normal and breast cancer cell lines [96].

\section{Prognostic microRNAs}

Since patients at higher risk might acquire differential therapeutic interventions, the search for prognostic biomarkers remains a continuous work in progress. Several gene-expression studies have identified new or improved miRNA prognostic markers, giving information on the course and outcome of disease in different subgroups of patients. To narrow this extensive area, we will emphasize those prognostic miRNAs that are being validated (that is, examined in more than one study or tested in the same study) but verified in more than one cohort or dataset. An overview of the miRNAs described in this review can be found in Table 8 and Table 9; for a more extensive list, see Additional file 1: Tables S2A and S2B.

\section{MicroRNAs associated with positive prognosis}

Let-7b and miR-205 Quesne and colleagues [97] revealed association of let-7b and miR-205 with prognosis in breast cancer. They applied in situ hybridization to study miRNA expression in a population-based breast tumor cohort and validated their findings by use of qRT-PCR. Deregulation of let-7b, which targets the oncogenes $H$ RAS and HMGA2, often occurs early in breast cancer progression and its expression is known to be downregulated during EMT and associated with less aggressive tumors [69,98-100]. Within luminal breast cancer, increased let-7b expression was positively associated with survival.

Additionally, the authors reported miR-205 as another miRNA with positive prognostic value [97]. MiR-205 regulates EMT by inhibiting E-cadherin suppression. MiR-205 expression is associated with tumors of ductal morphology and independently predicts survival within this tumor subtype.

Two independent studies verified these results. Ma and colleagues [101] showed how low let-7b expression levels in a heterogeneous breast cancer cohort associated with poor prognosis reflected in lower overall survival (OS) and relapse-free survival (RFS) times. Markou and colleagues [102] detected miRNA-205 levels in a heterogeneous breast cancer cohort and demonstrated how downregulation was associated with longer DFS.

Table 8 List of positive prognostic microRNA signatures in breast cancer

\begin{tabular}{|c|c|c|c|c|c|c|}
\hline \multicolumn{7}{|c|}{ miRNAs associated with positive outcome } \\
\hline \multirow[t]{2}{*}{ miRNA } & \multicolumn{3}{|l|}{ Case cohort } & \multicolumn{2}{|l|}{ Validation cohort } & \multirow[t]{2}{*}{ Reference } \\
\hline & Detection & Cells of origin & Number of samples & Technique & Number of samples & \\
\hline \multirow[t]{2}{*}{ let-7b } & LNA-ISH & Early invasive $B C$ & 1,432 & qRT-PCR & 40 & [97] \\
\hline & LNA-ISH & Heterogeneous BC & 80 & NR & NR & [101] \\
\hline \multirow[t]{2}{*}{ miR-205 } & LNA-ISH & Ductal BC & 1,475 & qRT-PCR & 40 & {$[97]$} \\
\hline & qRT-PCR & Heterogeneous BC & 84 & NR & NR & [102] \\
\hline miR-375 & Solexa deep sequencing & Stage $\|-\mid\| B C$ & 42 & qRT-PCR & 26 & {$[57]$} \\
\hline \multirow[t]{2}{*}{ miR-30a } & miRNA microarray & IDC & 221 & NR & NR & [104] \\
\hline & qRT-PCR & Heterogeneous BC & 96 & NR & NR & [108] \\
\hline miR-342-5p & miRNA microarray & Heterogeneous BC & 101 & miRNA microarray & 1,302 & [109] \\
\hline \multirow[t]{2}{*}{ miR-497 } & qRT-PCR & Heterogeneous BC & 128 & NR & NR & [111] \\
\hline & qRT-PCR & IDC & 48 & NR & NR & [110] \\
\hline
\end{tabular}


Table 9 List of negative prognostic microRNA signatures in breast cancer

\begin{tabular}{|c|c|c|c|c|c|c|}
\hline \multicolumn{7}{|c|}{ miRNAs associated with negative outcome } \\
\hline \multirow[t]{2}{*}{ miRNA } & \multicolumn{3}{|c|}{ Case cohort } & \multicolumn{2}{|c|}{ Validation cohort } & \multirow[t]{2}{*}{ Reference } \\
\hline & Detection & Cells of origin & Number of samples & Technique & Number of samples & \\
\hline miR-122 & Deep sequencing & Heterogeneous BC & 42 & qRT-PCR & 26 & [57] \\
\hline miR-27b-3p & qRT-PCR & TNBC & 58 & qRT-PCR & 41 & [113] \\
\hline \multirow[t]{2}{*}{ miR-21 } & qRT-PCR & IDC & 109 & NR & NR & [115] \\
\hline & qRT-PCR & Heterogeneous BC & 84 & NR & NR & [102] \\
\hline \multirow[t]{3}{*}{ miR-210 } & Deep sequencing & IDC & 118 & NR & NR & [75] \\
\hline & Meta-analysis & NR & 699 & Meta-analysis & Meta-analysis & [116] \\
\hline & Meta-analysis & $N R$ & 1,809 & Meta-analysis & Meta-analysis & [117] \\
\hline miR-9 & miRNA microarray & $E R^{+} B C$ & 16 & qRT-PCR & 52 & [120] \\
\hline miR-187 & LNA miRCURY & $\mathrm{LN}^{+} \mathrm{BC}$ & 117 & LNA miR probe & 470 & [121] \\
\hline \multirow[t]{2}{*}{ miR-155 } & qRT-PCR & Heterogeneous BC & 88 & $N R$ & $N R$ & [122] \\
\hline & qRT-PCR & Heterogeneous BC & 231 & $N R$ & $N R$ & [123] \\
\hline
\end{tabular}

BC, breast cancer; ER, estrogen receptor; IDC, invasive ductal carcinoma; LN, lymph node; LNA, Locked Nucleic Acid; miRNA, microRNA; NR, not reported; qRT-PCR, quantitative real-time polymerase chain reaction; TNBC, triple-negative breast cancer.

miR-375 Wu and colleagues [57] applied deep sequencing methods on blood of patients with primary stage II or III breast cancer to indicate the miR-375 prognostic value and validated these findings in an independent cohort by using qRT-PCR. miR-375 is known to inhibit migration and invasion which is partially carried out by targeting JAK2 [103]. A differential expression exists between patients with and without metastatic relapse. Higher circulating levels reflect more favorable clinical outcome in terms of pathologic complete response to NCT and absence of relapse [57].

miR-30a The prognostic features of miR-30a were investigated in 221 patients with IDC [104], showing that miR-30a, which has been implicated in regulation of several biological processes [105-107], negatively regulates vimentin expression and overexpression suppresses migration and invasiveness [104]. Reduced expression is associated with unfavorable outcome (decreased RFS and DFS). The prognostic value of miR-30a was also examined by Zhang and colleagues [108] on a heterogeneous set of 96 patients with breast cancer. The authors attributed the tumor-suppressive nature of this miRNA to its ability to target MTDH, thereby suppressing breast tumor growth and metastasis. Decreased expression of miR-30a was associated with an unfavorable outcome in terms of metastasis development [108].

miR-342-5p miR-342-5p has a role in cell cycle progression and cell growth regulation. The latest research by Leivonen and colleagues [109] demonstrated how higher expression of miR-342-5p, which is an efficient negative regulator of the HER2 pathway, was significantly associated with better survival in two heterogeneous breast cancer cohorts.

miR-497 miR-497 is a tumor-suppressive miRNA and its biological role is found in the regulation of the nervous system. Several studies examined miR-497 and found its expression to be significantly decreased in breast cancer compared with normal breast and negatively correlated with adverse clinicopathological characteristics. Shen and colleagues [110] reported how elevated miR-497 expression rendered IDC patients with better prognosis. An independent study verified its prognostic role in a population-based breast cancer cohort, in which higher expression was correlated with a better 5-year DFS and OS [111].

\section{MicroRNAs associated with negative prognosis}

miR-122 Wu and colleagues [57] identified circulating miR-122 in a heterogeneous breast cancer exploration and validation cohort, by sequencing and RT-PCR, respectively. They found miR-122 to be associated with outcome in terms of relapse and identified a distinct expression in patients undergoing metastatic relapse and those who remained relapse-free.

miR-27b-3p The miR-27 family is known to regulate cell cycle progression and survival by targeting the tumor-suppressive FOXO1 gene and is highly expressed in breast cancer [112]. In a recent study, Shen and colleagues [113] aimed to identify and validate a prognostic signature for patients with TNBC $(n=58)$ and found that lymph node status and miR-27b-3p were independent predictors of poor prognosis in terms of distant 
metastasis-free survival. This result was validated in a TNBC cohort $(n=41)$ [113].

miR-21 miR-21, which has its biological role in development, morphogenesis, and differentiation, is known to be overexpressed in breast cancer [114]. The significance of this miRNA as a prognostic factor was examined in two independent studies. Lee and colleagues [115] found significantly higher expressions in IDC compared with normal breast tissue, which positively associated with tumor size, stage, grade, and Ki-67 expression. A higher miR-21 expression also correlated with ER negativity and HER2 positivity. A lower OS could be noticed in patients with higher miR-21 expression levels [115]. In a more recent study, miR-21 was found to inversely correlate with DFS [102].

miR-210 Volinia and colleagues [75] used deep sequencing to determine miR-210 in patients with IDC. miR-210 showed association with time to metastasis and OS by uni- and multivariate analyses. Various breast cancer genes-such as BRCA1, E-cadherin, PARP1, and RB1with an antagonistic behavior to miR-210 were identified. More recently, systematic reviews and meta-analyses of previous clinical research were performed to recapitulate the significance of increased miR-210 in the prognosis of cancer. Summarizing nine published studies, the authors found that miR-210 could predict outcome, especially in patients with breast cancer, and that miR-210 overexpression predicts DFS and RFS [116,117].

miR-9 The functional significance of miR-9 is evidenced by its regulative role in neurogenesis, development, and apoptosis. Dysregulation of miR-9 influences proliferation or metastasis formation and has been reported in cancer [118]. In breast cancer, upregulation of miR-9 suppresses E-cadherin, leading to increased cell motility and invasiveness [119]. Zhou and colleagues [120] found miR-9 to discriminate between cases with and without local recurrence (LR), in which the latter group showed a significantly lower expression. In $\mathrm{ER}^{+}$cases, a lower 10 -year LR-free survival was seen in patients with high miR-9 expression by using miRNA arrays [120].

miR-187 Using an in silico method in two independent breast cancer cohorts, Mulrane and colleagues [121] identified and validated miRNA-187 as being involved in breast cancer progression. miR-187 is independently associated with poor outcome in breast cancer (particularly, lymph node-positive samples) in terms of reduced breast cancer-specific survival.

miR-155 Several studies demonstrated the involvement of miR-155 in biological processes, such as cell survival, growth, migration, and invasion [23,25]. Song and colleagues [122] found a significantly higher miR-155 expression in formalin-fixed paraffin-embedded tumor compared with normal tissues. Multivariate analysis showed an inverse (yet insignificant) correlation with breast cancer outcome in terms of OS. Recently, Kong and colleagues [123] verified these findings and reported miR-155 to be frequently upregulated in various types of cancer where it plays pro-angiogenic, proliferative, and migratory roles. Moreover, they noticed miR-155 expression levels to be associated with poor prognosis in terms of OS [123].

\section{MicroRNA biogenesis}

MiRNA biogenesis (see Figure 2 for the canonical pathway of miRNA biogenesis) affects both the quantity and quality of miRNAs, providing a link between biogenesis and the diagnostic, predictive, and prognostic power of miRNAs.

\section{MicroRNA biogenesis and the diagnostic potential of microRNAs}

A differential expression of miRNA-processing enzymes may result in an altered turnover of pri- and premiRNAs, which may influence the biology and etiology of cancer. We [68] and others [69] have seen that the expression of miRNA biogenesis genes varies between different molecular subtypes. Therefore, the hypothesis exists that molecular changes in miRNA-processing enzymes might be responsible for the subtype-specific variation of miRNA profiles.

Blenkiron and colleagues [69] demonstrated how DICER1 and AGO2 showed a significantly lower and respectively higher expression in the more aggressive subtypes. Higher AGO2 and DROSHA levels and lower DICER1 levels were detected in ER-negative breast cancers.

\section{MicroRNA biogenesis and the predictive and prognostic potential of microRNAs}

Aside from affecting the quantity, the miRNA biogenesis cascade may also affect the quality and function of miRNAs. MiRNAs exert their function in collaboration with various proteins in the RISC complex, such as the processing enzymes AGO2, DICER1, and TARBP2. When overexpression of a certain miRNA results in a predictive or prognostic potential, this property could be negated by inadequate expression of AGO2, the catalytic subunit of RISC. Therefore, the prognostic or predictive capability of certain miRNAs may depend on the status of particular miRNA-processing enzymes, which may in fact explain the discrepancy found between several studies.

The role of miRNA-processing enzymes in breast cancer prognosis was also examined in different studies. For 


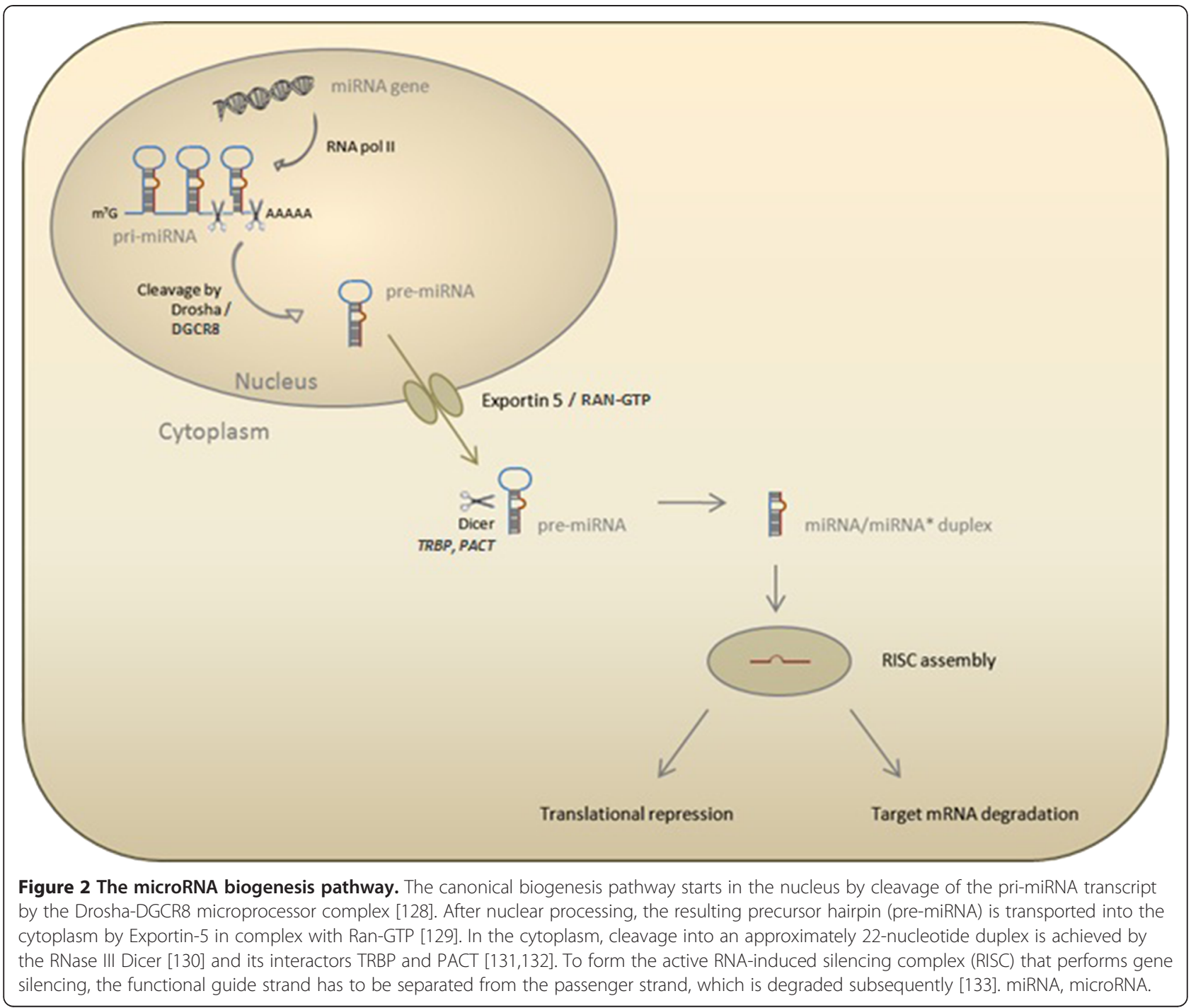

example, lower DICER1 levels are significantly associated with lower metastasis and DFS rates [124]. In terms of predictive potential, a loss of Drosha was independently associated with better response to chemotherapeutic and endocrine therapy [125]. In a case-control study, Leaderer and colleagues [126] reported how higher methylation levels in the XPO5 promoter region were associated with reduced risk of breast cancer. Finally, Sung and colleagues [127] reported seven single-nucleotide polymorphisms in miRNA biogenesis genes to be significantly associated with breast cancer survival.

\section{Conclusions}

Over recent years, several research groups have explored the regulatory potential of the miRNA class of small non-coding RNAs. Differences in expression of these miRNAs were used to explain the heterogeneity and disease pathology of several types of cancer. Aside from understanding the biochemical mechanisms these molecules have in gene regulation, we are beginning to understand the carcinogenic mechanisms and pathways these small molecules could influence. Due to their obvious association with carcinogenesis, and considering their promising diagnostic and therapeutic potential, miRNAs will steadily be investigated to discover their effect on a patient's disease.

Additionally, miRNAs represent a novel class of potential biomarkers for diagnosis, prediction of treatment, or prognosis, which are essential to improve patient management. In this review, we focused on miRNAs validated by more than one study or where results rely on preclinical as well as clinical evidence. However, it needs to be emphasized that the major challenge in identifying diagnostic, predictive, and prognostic miRNAs still resides in the need to firmly validate these findings in additional independent cohorts or by additional preclinical/clinical verification studies. Also, it is important to integrate multivariate testing since many individual identified miRNAs 
lose their significance when correcting for multiple testing. One should also take into account that some inconsistencies can be partly attributed to differences in subtype distribution or cells of origin. In this way, sufficient experimental evidence can be obtained in order to provide more power to the currently insufficiently strong miRNA markers so that they could be employed in clinical decision-making.

\section{Additional file}

Additional file 1: Table S1. Predictive microRNAs - microRNAs involved in response (sensitivity/resistance) to conventional breast cancer therapeutic strategies. Table S2A. Prognostic microRNAs: list of major positive prognostic microRNA signatures in breast cancer. Table S2B. Prognostic microRNAs: list of major negative prognostic microRNA signatures in breast cancer.

\begin{abstract}
Abbreviations
BRCA1: Breast cancer 1, early onset; Cx43: Connexin 43; DFS: Disease-free survival; EMT: Epithelial-to-mesenchymal transition; EPO: Erythropoietin; ER: Estrogen receptor; ERa: Estrogen receptor alpha; FOXO3: Forkhead box protein 3; HIF1A: Hypoxia-inducible factor 1 a; HMGB3: High mobility group box 3 gene; HOXD10: Homeobox D10; IBC: Inflammatory breast cancer; IDC: Invasive ductal carcinoma; LL: Interleukin; LR: Local recurrence; miRNA: microRNA; MTDH: Metadherin; NCT: Neoadjuvant chemotherapy; NF-KB: Nuclear factor-kappa-B; OS: Overall survival; PARP: Poly (ADP-ribose) polymerase; PR: Progesterone receptor; qRT-PCR: Quantitative real-time polymerase chain reaction; RFS: Relapse-free survival; RhoA: Ras homolog gene family; RISC: RNA-induced silencing complex; RT-PCR: Real-time polymerase chain reaction; SOCS1: Suppressor of cytokine signaling 1; SOX4: SRY-related HMG-box4; TNBC: Triple-negative breast cancer; TNC: Tenascin C; UTR: Untranslated region; WAVE3: WAS protein family, member 3.
\end{abstract}

\section{Competing interests}

The authors declare that they have no competing interests.

\section{Author details}

'Department of Oncology, University Hospitals Leuven and Catholic University Leuven, Herestraat 49, Leuven B-3000, Belgium. ${ }^{2}$ CORE, Faculty of Medicine and Health Sciences, University of Antwerp, Universiteitsplein 1 , Antwerp B-2016, Belgium.

\section{Published online: 18 February 2015}

\section{References}

1. Bombonati A, Sgroi DC. The molecular pathology of breast cancer progression. J Pathol. 2011;223:308-18.

2. Curtis C, Shah SP, Chin SF, Turashvili G, Rueda OM, Dunning MJ, et al. The genomic and transcriptomic architecture of 2,000 breast tumours reveals novel subgroups. Nature. 2012;486:346-52.

3. He L, Hannon GJ. MicroRNAs: small RNAs with a big role in gene regulation. Nat Rev Genet. 2004:5:522-31.

4. Dvinge H, Git A, Gräf S, Salmon-Divon M, Curtis C, Sottoriva A, et al. The shaping and functional consequences of the microRNA landscape in breast cancer. Nature. 2013:497:378-82.

5. Pillai RS. MicroRNA function: multiple mechanisms for a tiny RNA? RNA. 2005:11:1753-61.

6. Lu J, Getz G, Miska EA, Alvarez-Saavedra E, Lamb J, Peck D, et al. MicroRNA expression profiles classify human cancers. Nature. 2005;435:834-8.

7. Volinia S, Calin GA, Liu C-G, Ambs S, Cimmino A, Petrocca F, et al. A microRNA expression signature of human solid tumors defines cancer gene targets. Proc Natl Acad Sci U S A. 2006;103:2257-61.

8. Tang J, Ahmad A, Sarkar FH. The role of microRNAs in breast cancer migration, invasion and metastasis. Int J Mol Sci. 2012;13:13414-37.
9. Chen L, Bourguignon LY. Hyaluronan-CD44 interaction promotes C-Jun signaling and miRNA21 expression leading to BCl-2 expression and chemoresistance in breast cancer cells. Mol Cancer. 2014;13:52.

10. Ahmad A, Aboukameel A, Kong D, Wang Z, Sethi S, Chen W, et al. Phosphoglucose isomerase/autocrine motility factor mediates epithelial-mesenchymal transition regulated by miR-200 in breast cancer cells. Cancer Res. 2011;71:3400-9.

11. Baffa R, Fassan M, Volinia S, OHara B, Liu C, Palazzo JP, et al. MicroRNA expression profiling of human metastatic cancers identifies cancer gene targets. J Pathol. 2009;219:214-21.

12. O'Day E, Lal A. MicroRNAs and their target gene networks in breast cancer. Breast Cancer Res. 2010;12:201.

13. Calin GA, Sevignani C, Dumitru CD, Hyslop T, Noch E, Yendamuri S, et al. Human microRNA genes are frequently located at fragile sites and genomic regions involved in cancers. Proc Natl Acad Sci U S A. 2004;101(9):2999-3004.

14. Iorio MV, Casalini P, Piovan C, Braccioli L, Tagliabue E. Breast cancer and microRNAs: therapeutic impact. Breast. 2011;20:563-70.

15. Corcoran C, Friel AM, Duffy MJ, Crown J, O'Driscoll L. Intracellular and extracellular microRNAs in breast cancer. Clin Chem. 2011;57:18-32.

16. Ma L, Teruya-Feldstein J, Weinberg RA. Tumour invasion and metastasis initiated by microRNA-10b in breast cancer. Nature. 2007:449:682-8.

17. Gabriely G, Teplyuk NM, Krichevsky AM. Context effect: microRNA-10b in cancer cell proliferation, spread and death. Autophagy. 2011;7:1384-6.

18. Huang TH, Wu F, Loeb GB, Hsu R, Heidersbach A, Brincat A, et al. Upregulation of miR-21 by HER2/neu signaling promotes cell invasion. J Biol Chem. 2009;284:18515-24.

19. Han M, Wang Y, Liu M, Bi X, Bao J, Zeng N, et al. MiR-21 regulates epithelial-mesenchymal transition phenotype and hypoxia-inducible factor-1a expression in third-sphere forming breast cancer stem cell-like cells. Cancer Sci. 2012;103:1058-64.

20. Qi L, Bart J, Tan LP, Platteel I, Sluis T, Huitema S, et al. Expression of miR-21 and its targets (PTEN, PDCD4, TM1) in flat epithelial atypia of the breast in relation to ductal carcinoma in situ and invasive carcinoma. BMC Cancer. 2009;9:163.

21. Song B, Wang C, Liu J, Wang X, Lv L, Wei L, et al. MicroRNA-21 regulates breast cancer invasion partly by targeting tissue inhibitor of metalloproteinase 3 expression. J Exp Clin Cancer Res. 2010;29:29.

22. Lu Z, Liu M, Stribinskis V, Klinge CM, Ramos KS, Colburn NH, et al. MicroRNA-21 promotes cell transformation by targeting the programmed cell death 4 gene. Oncogene. 2008;27:4373-9.

23. Jiang S, Zhang HW, Lu MH, He XH, Li Y, Gu H, et al. MicroRNA-155 functions as an OncomiR in breast cancer by targeting the suppressor of cytokine signaling 1 gene. Cancer Res. 2010;70:3119-27.

24. Zhang CM, Zhao J, Deng HY. MiR-155 promotes proliferation of human breast cancer MCF-7 cells through targeting tumor protein 53-induced nuclear protein 1. J Biomed Sci. 2013;20:79.

25. Kong W, He L, Coppola M, Guo J, Esposito NN, Coppola D, et al. MicroRNA-155 regulates cell survival, growth, and chemosensitivity by targeting FOXO3a in breast cancer. J Biol Chem. 2010;285:17869-79.

26. Huang GQ, Gumireddy K, Schrier M, le Sage C, Nagel R, Coukos G, et al. The microRNAs miR-373 and miR-520c promote tumour invasion and metastasis. Nat Cell Biol. 2008;10:202-10.

27. Yan GR, Xu SH, Tan ZL, Liu L, He QY. Global identification of miR-373regulated genes in breast cancer by quantitative proteomics. Proteomics. 2011;11:912-20

28. Zhang B, Pan X, Cobb GP, Anderson TA. microRNAs as oncogenes and tumor suppressors. Dev Biol. 2007;302:1-12.

29. Ferracin M, Bassi C, Pedriali M, Pagotto S, D'Abundo L, Zagatti B, et al. miR-125b targets erythropoietin and its receptor and their expression correlates with metastatic potential and ERBB2/HER2 expression. Mol Cancer. 2013;12:130.

30. Feliciano A, Castellvi J, Artero-Castro A, Leal JA, Romagosa C, Hernández-Losa J, et al. miR-125b acts as a tumor suppressor in breast tumorigenesis via its novel direct targets ENPEP, CK2-a, CCNJ, and MEGF9. PLoS One. 2013;8:e76247.

31. Scott GK, Goga A, Bhaumik D, Berger CE, Sullivan CS, Benz CC. Coordinate suppression of ERBB2 and ERBB3 by enforced expression of micro-RNA miR-125a or miR-125b. J Biol Chem. 2007;282:1479-86.

32. Liu J, Mao Q, Liu Y, Hao X, Zhang S, Zhang J. Analysis of miR-205 and miR-155 expression in the blood of breast cancer patients. Chin J Cancer Res. 2013;25:46-54. 
33. Elgamal OA, Park JK, Gusev Y, Azevedo-Pouly AC, Jiang J, Roopra A, et al. Tumor suppressive function of mir-205 in breast cancer is linked to HMGB3 regulation. PLoS One. 2013;8:e76402.

34. Jiang $H$, Wang $P$, Li X, Wang $Q$, Deng ZB, Zhuang $X$, et al. Restoration of miR17/20a in solid tumor cells enhances the natural killer cell antitumor activity by targeting Mekk2. Cancer Immunol Res. 2014;2:789-99.

35. Fan M, Sethuraman A, Brown M, Sun W, Pfeffer LM. Systematic analysis of metastasis-associated genes identifies miR-17-5p as a metastatic suppressor of basal-like breast cancer. Breast Cancer Res Treat. 2014;146:487-502.

36. Li Y, Hong F, Yu Z. Decreased expression of microRNA-206 in breast cancer and its association with disease characteristics and patient survival. J Int Med Res. 2013;41:596-602.

37. Fu Y, Jiang BQ, Wu Y, Li ZD, Zhuang ZG. Hsa-miR-206 inhibits the migration and invasion of breast cancer by targeting Cx43. Zhonghua Yi XueZaZhi. 2013;93:2890-4

38. Zhang HF, Xu LY, Li E. A family of pleiotropically acting microRNAs in cancer progression, miR-200: potential cancer therapeutic targets. Curr Pharm Des. 2014;20:1896-903.

39. Roy SS, Gonugunta VK, Bandyopadhyay A, Rao MK, Goodall GJ, Sun LZ, et al. Significance of PELP1/HDAC2/miR-200 regulatory network in EMT and metastasis of breast cancer. Oncogene. 2014;33:3707-16.

40. Castilla MÁ, Díaz-Martín J, Sarrió D, Romero-Pérez L, López-García MÁ, Vieites $B$, et al. MicroRNA-200 family modulation in distinct breast cancer phenotypes. PLoS One. 2012;7:e47709.

41. Xiang M, Birkbak NJ, Vafaizadeh V, Walker SR, Yeh JE, Liu S, et al. STAT3 induction of miR-146b forms a feedback loop to inhibit the NF-kB to IL-6 signaling axis and STAT3-driven cancer phenotypes. Sci Signal. 2014;7:ra11.

42. Bhaumik D, Scott GK, Schokrpur S, Patil CK, Campisi J, Benz CC. Expression of microRNA-146 suppresses NF-kB activity with reduction of metastatic potential in breast cancer cells. Oncogene. 2008;27:5643-7.

43. Png KJ, Halberg N, Yoshida M, Tavazoie SF. A microRNA regulon that mediates endothelial recruitment and metastasis by cancer cells. Nature. 2012;481:190-4.

44. Tavazoie SF, Alarcón C, Oskarsson T, Padua D, Wang Q, Bos PD, et al. Endogenous human microRNAs that suppress breast cancer metastasis. Nature. 2008;451:147-52.

45. Zhang $\mathrm{S}$, Kim K, Jin UH, Pfent $\mathrm{C}$, $\mathrm{Cao} \mathrm{H}$, Amendt B, et al. Aryl hydrocarbon receptor agonists induce microRNA-335 expression and inhibit lung metastasis of estrogen receptor negative breast cancer cells. Mol Cancer Ther. 2012;11:108-18

46. Valastyan S, Reinhardt F, Benaich N, Calogrias D, Szász AM, Wang ZC, et al. A pleiotropically acting microRNA, miR-31, inhibits breast cancer metastasis. Cell. 2009;137:1032-46.

47. Augoff K, McCue B, Plow EF, Sossey-Alaoui K. miR-31 and its host gene InCRNA LOC554202 are regulated by promoter hypermethylation in triple-negative breast cancer. Mol Cancer. 2012;11:5.

48. Sossey-Alaoui K, Downs-Kelly E, Das M, Izem L, Tubbs R, Plow EF. WAVE3, an actin remodeling protein, is regulated by the metastasis suppressor microRNA, miR-31, during the invasion-metastasis cascade. Int J Cancer. 2011;129:1331-43.

49. Kasinski AL, Slack FJ. MicroRNAs en route to the clinic: progress in validating and targeting microRNAs for cancer therapy. Nat Rev Cancer. 2011;11:849-64

50. Garcia Al, Buisson M, Bertrand P, Rimokh R, Rouleau E, Lopez BS, et al. Down-regulation of BRCA1 expression by miR-146a and miR-146b-5p in triple negative sporadic breast cancers. EMBO Mol Med. 2011;3:279-90.

51. Jiang $H$, Zhang $G, W u ~ J H$, Jiang CP. Diverse roles of miR-29 in cancer (review). Oncol Rep. 2014;31:1509-16.

52. Keklikoglou I, Koerner C, Schmidt C, Zhang JD, Heckmann D, Shavinskaya A, et al. MicroRNA-520/373 family functions as a tumor suppressor in estrogen receptor negative breast cancer by targeting NF-kB and TGF-b signaling pathways. Oncogene. 2012;31:4150-63.

53. Várallyay É, Burgyan J, Havelda J. MicroRNA detection by northern blotting using locked nucleic acid probes. Nat Protoc. 2008;3:190-6.

54. Hammond SM. microRNA detection comes of age. Nat Methods. 2006:3:12-3

55. Balcells I, Cirera S, Busk PK. Specific and sensitive quantitative RT-PCR of miRNAs with DNA primers. BMC Biotechnol. 2011;11:70.

56. Li W, Ruan K. MicroRNA detection by microarray. Anal Bioanal Chem. 2009;394:1117-24
57. Wu X, Somlo G, Yu Y, Palomares MR, Li AX, Zhou W, et al. De novo sequencing of circulating miRNAs identifies novel markers predicting clinical outcome of locally advanced breast cancer. J Transl Med. 2012;10:42.

58. Creighton CJ, Reid JG, Gunaratne PH. Expression profiling of microRNAs by deep sequencing. Brief Bioinform. 2009;10:490-7.

59. Vandesompele J, De Preter K, Pattyn F, Poppe B, Van Roy N, De Paepe A et al. Accurate normalization of real-time quantitative RT-PCR data by geometric averaging of multiple internal control genes. Genome Biol. 2002;3:1-12

60. van Schooneveld E, Wouters MC, Van der Auwera I, Peeters DJ, Wildiers $H_{\text {, }}$ Van Dam PA, et al. Expression profiling of cancerous and normal breast tissues identifies microRNAs that are differentially expressed in serum from patients with (metastatic) breast cancer and healthy volunteers. Breast Cancer Res. 2012;14:R34.

61. Mestdagh $P$, Van Vlierberghe P, De Weer A, Muth D, Westermann F, Speleman F, et al. A novel and universal method for microRNA RT-qPCR data normalization. Genome Biol. 2009;10:R64.

62. Kodahl AR, Lyng MB, Binder H, Cold S, Gravgaard K, Knoop AS, et al. Novel circulating microRNA signature as a potential non-invasive multi-marker test in ER-positive early-stage breast cancer: a case control study. Mol Oncol. 2014;8:874-83.

63. Wang F, Hou J, Jin W, Li J, Yue Y, Jin H, et al. Increased circulating microRNA-155 as a potential biomarker for breast cancer screening: a meta-analysis. Molecules. 2014;19:6282-93.

64. Chan M, Liaw CS, Ji SM, Tan HH, Wong CY, Thike AA, et al. Identification of circulating microRNA signatures for breast cancer detection. Clin Cancer Res. 2013;19:4477-87.

65. Cuk K, Zucknick M, Heil J, Madhavan D, Schott S, Turchinovich A, et al. Circulating microRNAs in plasma as early detection markers for breast cancer. Int J Cancer. 2013;132:1602-12.

66. Ng EK, Li R, Shin WY, Jin HC, Leung CP, Ma ES, et al. Circulating microRNAs as specific biomarkers for breast cancer detection. PLoS One. 2013:8:e53141.

67. Godfrey AC, Xu Z, Weinberg CR, Getts RC, Wade PA, DeRoo LA, et al. Serum microRNA expression as an early marker for breast cancer risk in prospectively collected samples from the Sister Study cohort. Breast Cancer Res. 2013:15:R42

68. Van der Auwera I, Yu W, Suo L, Van Neste L, Van Dam P, Van Marck EA, et al. Array-based DNA methylation profiling for breast cancer subtype discrimination. PLoS One. 2010;5:e12616.

69. Blenkiron C, Goldstein LD, Thorne NP, Spiteri I, Chin S-F, Dunning MJ, et al. MicroRNA expression profiling of human breast cancer identifies new markers of tumor subtype. Genome Biol. 2007:8:R214

70. Serpico D, Molino L, Di Cosimo S. microRNAs in breast cancer development and treatment. Cancer Treat Rev. 2014;40:595-604.

71. de Rinaldis E, Gazinska P, Mera A, Modrusan Z, Fedorowicz GM, Burford B, et al. Integrated genomic analysis of triple-negative breast cancers reveals novel microRNAs associated with clinical and molecular phenotypes and sheds light on the pathways they control. BMC Genomics. 2013;14:643.

72. Lowery AJ, Miller N, Devaney A, McNeill RE, Davoren PA, Lemetre C, et al. MicroRNA signatures predict oestrogen receptor, progesterone receptor and HER2/neu receptor status in breast cancer. Breast Cancer Res. 2009;11:R27.

73. Crippa E, Lusa L, De Cecco L, Marchesi E, Calin GA, Radice P, et al. miR-342 regulates BRCA1 expression through modulation of ID4 in breast cancer. PLoS One. 2014;9:e87039.

74. He YJ, Wu JZ, Ji MH, Ma T, Qiao EQ, Ma R, et al. miR-342 is associated with estrogen receptor-a expression and response to tamoxifen in breast cancer. Exp Ther Med. 2013:5:813-8.

75. Volinia S, Galasso M, Sana ME, Wise TF, Palatini J, Huebner K, et al. Breast cancer signatures for invasiveness and prognosis defined by deep sequencing of microRNA. Proc Natl Acad Sci U S A. 2012;109:1-6.

76. Giricz O, Reynolds PA, Ramnauth A, Liu C, Wang T, Stead L, et al. Hsa-miR375 is differentially expressed during breast lobular neoplasia and promotes loss of mammary acinar polarity. J Pathol. 2012;226:108-19.

77. Van der Auwera I, Limame R, van Dam P, Vermeulen PB, Dirix LY, Van Laere SJ. Integrated miRNA and mRNA expression profiling of the inflammatory breast cancer subtype. Br J Cancer. 2010;103:532-41.

78. Lerebours F, Cizeron-Clairac G, Susini A, Vacher S, Mouret-Fourme E, Belichard C, et al. miRNA expression profiling of inflammatory breast cancer identifies a 5-miRNA signature predictive of breast tumor aggressiveness. Int J Cancer. 2013;133:1614-23. 
79. Masri S, Liu Z, Phung S, Wang E, Yuan YC, Chen S. The role of microRNA-128a in regulating TGFbeta signaling in letrozole-resistant breast cancer cells. Breast Cancer Res Treat. 2010;124:89-99.

80. Ward A, Balwierz A, Zhang JD, Küblbeck M, Pawitan Y, Hielscher T, et al. Re-expression of microRNA-375 reverses both tamoxifen resistance and accompanying EMT-like properties in breast cancer. Oncogene. 2013;32:1173-82

81. Cittelly DM, Das PM, Spoelstra NS, Edgerton SM, Richer JK, Thor AD, et al Downregulation of miR-342 is associated with tamoxifen resistant breast tumors. Mol Cancer. 2010;9:317.

82. Zhao JJ, Lin J, Yang H, Kong W, He L, Ma X, et al. MicroRNA-221/222 negatively regulates estrogen receptor alpha and is associated with tamoxifen resistance in breast cancer. J Biol Chem. 2008;283:31079-86.

83. Wei Y, Lai X, Yu S, Chen S, Ma Y, Zhang Y, et al. Exosomal miR-221/222 enhances tamoxifen resistance in recipient ER-positive breast cancer cells. Breast Cancer Res Treat. 2014;147:423-31.

84. Gan R, Yang Y, Yang X, Zhao L, Lu J, Meng QH. Downregulation of miR-221/ 222 enhances sensitivity of breast cancer cells to tamoxifen through upregulation of TIMP3. Cancer Gene Ther. 2014;21:290-6.

85. Rao X, Di Leva G, Li M, Fang F, Devlin C, Hartman-Frey C, et al. MicroRNA-221/222 confers breast cancer fulvestrant resistance by regulating multiple signaling pathways. Oncogene. 2011;30:1082-97.

86. Shibahara Y, Miki Y, Onodera Y, Hata S, Chan MS, Yiu CC, et al. Aromatase inhibitor treatment of breast cancer cells increases the expression of let-7f, a microRNA targeting CYP19A1. J Pathol. 2012:227:357-66.

87. Jung EJ, Santarpia L, Kim J, Esteva FJ, Moretti E, Buzdar AU, et al. Plasma microRNA 210 levels correlate with sensitivity to trastuzumab and tumor presence in breast cancer patients. Cancer. 2012;118:2603-14.

88. Zhou M, Liu Z, Zhao Y, Ding Y, Liu H, Xi Y, et al. MicroRNA-125b confers the resistance of breast cancer cells to paclitaxel through suppression of pro-apoptotic BCl-2 antagonist killer 1 (Bak1) expression. J Biol Chem. 2010;285:21496-507.

89. Wang H, Tan G, Dong L, Cheng L, Li K, Wang Z, et al. Circulating MiR-125b as a marker predicting chemoresistance in breast cancer. PLoS One. 2012;7:e34210.

90. Climent J, Dimitrow P, Fridlyand J, Palacios J, Siebert R, Albertson DG, et al. Deletion of chromosome 11q predicts response to anthracycline-based chemotherapy in early breast cancer. Cancer Res. 2007:67:818-26.

91. Bockhorn J, Dalton R, Nwachukwu C, Huang S, Prat A, Yee K, et al. MicroRNA-30c inhibits human breast tumour chemotherapy resistance by regulating TWF1 and IL-11. Nat Commun. 2013:4:1393.

92. Fang $Y$, Shen $\mathrm{H}$, Cao $Y$, Li H, Qin R, Chen Q, et al. Involvement of miR-30c in resistance to doxorubicin by regulating YWHAZ in breast cancer cells. Braz J Med Biol Res. 2014;47:60-9.

93. Mei M, Ren Y, Zhou X, Yuan XB, Han L, Wang GX, et al. Downregulation of miR-21 enhances chemotherapeutic effect of taxol in breast carcinoma cells. Technol Cancer Res Treat. 2010;9:77-86.

94. Dong J, Zhao YP, Zhou L, Zhang TP, Chen G. Bcl-2 upregulation induced by miR-21 via a direct interaction is associated with apoptosis and chemoresistance in MIA PaCa-2 pancreatic cancer cells. Arch Med Res. 2011:42:8-14.

95. Kato M, Paranjape T, Müller RU, Nallur S, Gillespie E, Keane K, et al. The mir-34 microRNA is required for the DNA damage response in vivo in C. elegans and in vitro in human breast cancer cells. Oncogene. 2009:28:2419-24.

96. Stankevicins L, da Silva AP A, Ventura Dos Passos F, Dos Santos Ferreira E, Menks Ribeiro MC, G David M, et al. MiR-34a is up-regulated in response to low dose, low energy $\mathrm{X}$-ray induced DNA damage in breast cells. Radiat Oncol. 2013;8:231.

97. Quesne JL, Jones J, Warren J, Dawson S-J, Ali HR, Bardwell H, et al. Biological and prognostic associations of miR-205 and let-7b in breast cancer revealed by in situ hybridization analysis of micro-RNA expression in arrays of archival tumour tissue. J Pathol. 2012;227:306-14.

98. Sempere LF, Christensen M, Silahtaroglu A, Bak M, Heath CV, Schwartz G et al. Altered microRNA expression confined to specific epithelial cell subpopulations in breast cancer. Cancer Res. 2007:67:11612-20.

99. Dangi-Garimella S, Yun J, Eves EM, Newman M, Erkeland SJ, Hammond SM, et al. Raf kinase inhibitory protein suppresses a metastasis signalling cascade involving LIN28 and let-7. EMBO J. 2009;28:347-58.
100. Yu F, Yao H, Zhu P, Zhang X, Pan Q, Gong C, et al. let-7 regulates self renewal and tumorigenicity of breast cancer cells. Cell. 2007;131:1109-23

101. Ma L, Li GZ, Wu ZS, Meng G. Prognostic significance of let-7b expression in breast cancer and correlation to its target gene of BSG expression. Med Oncol. 2014;31:1-5.

102. Markou A, Yousef GM, Stathopoulos E, Georgoulias V, Lianidou E. Prognostic significance of metastasis-related microRNAs in early breast cancer patients with a long follow-up. Clin Chem. 2014;60:197-205.

103. Xu Y, Jin J, Liu Y, Huang Z, Deng Y, You T, et al. Snail-regulated miR-375 inhibits migration and invasion of gastric cancer cells by targeting JAK2. PLoS One. 2014;9:e99516.

104. Cheng CW, Wang HW, Chang CW, Chu HW, Chen CY, Yu JC, et al. MicroRNA-30a inhibits cell migration and invasion by downregulating vimentin expression and is a potential prognostic marker in breast cancer. Breast Cancer Res Treat. 2012;134:1081-93

105. Agrawal $R$, Tran U, Wessely $O$. The miR-30 miRNA family regulates xenopus pronephros development and targets the transcription factor $\mathrm{Xlim1/Lh \times 1.}$ Development. 2009;136:3927-36.

106. Martinez I, Cazalla D, Almstead LL, Steitz JA, DiMaio D. miR-29 and miR-30 regulate B-Myb expression during cellular senescence. Proc Natl Acad Sci U S A. 2011;108:522-7.

107. Xia Z, Zhang N, Jin H, Yu Z, Xu G, Huang Z. Clinical significance of astrocyte elevated gene-1 expression in human oligodendrogliomas. Clin Neurol Neurosurg. 2010;112:413-9.

108. Zhang N, Wang X, Huo Q, Sun M, Cai C, Liu Z, et al. MicroRNA-30a suppresses breast tumor growth and metastasis by targeting metadherin. Oncogene. 2014;33:3119-28.

109. Leivonen S-K, Sahlberg KK, Mäkelä R, Due EU, Kallioniemi O, Børresen-Dale $A-L$, et al. High-throughput screens identify microRNAs essential for HER2 positive breast cancer cell growth. Mol Oncol. 2014;8:93-104.

110. Shen L, Li J, Xu L, Ma J, Li H, Xiao X, et al. miR-497 induces apoptosis of breast cancer cells by targeting Bcl-w. Exp Ther Med. 2012;3:475-80.

111. Wang S, Li H, Wang J, Wang D. Expression of microRNA-497 and its prognostic significance in human breast cancer. Diagn Pathol. 2013:8:172.

112. Guttilla IK, White BA. Coordinate regulation of FOXO1 by miR-27a, miR-96, and miR-182 in breast cancer cells. J Biol Chem. 2009:284:23204-16.

113. Shen S, Sun Q, Liang Z, Cui X, Ren X, Chen H, et al. A prognostic model of triple-negative breast cancer based on miR-27b-3p and node status. PLoS One. 2014;9:e100664

114. Si ML, Zhu S, Wu H, Lu Z, Wu F, Mo YY. miR-21-mediated tumor growth. Oncogene. 2007;26:2799-803.

115. Lee JA, Lee HY, Lee ES, Kim I, Bae JW. Prognostic implications of microRNA-21 overexpression in invasive ductal carcinomas of the breast. J Breast Cancer. 2011;14:269.

116. Li M, Ma X, Li M, Zhang B, Huang J, Liu L, et al. Prognostic role of microRNA-210 in various carcinomas: a systematic review and meta-analysis. Dis Markers. 2014;2014:106197.

117. Wang J, Zhao J, Shi M, Ding Y, Sun H, Yuan F, et al. Elevated expression of miR-210 predicts poor survival of cancer patients: a systematic review and meta-analysis. PLoS One. 2014;9:e89223.

118. Yuva-Aydemir Y, Simkin A, Gascon E, Gao FB. MicroRNA-9: functional evolution of a conserved small regulatory RNA. RNA Biol. 2011;8:557-64.

119. Ma L, Young J, Prabhala H, Pan E, Mestdagh P, Muth D, et al. miR-9, a MYC/ MYCN-activated microRNA, regulates E-cadherin and cancer metastasis. Nat Cell Biol. 2010:12:247-56

120. Zhou X, Marian C, Makambi KH, Kosti O, Kallakury BVS, Loffredo CA, et al. MicroRNA-9 as potential biomarker for breast cancer local recurrence and tumor estrogen receptor status. PLoS One. 2012;7:e39011.

121. Mulrane L, Madden SF, Brennan DJ, Gremel G, McGee SF, McNally S, et al. miR-187 is an independent prognostic factor in breast cancer and confers increased invasive potential in vitro. Clin Cancer Res. 2012;18:6702-13.

122. Song CG, Wu XY, Wang C, Fu FM, Shao ZM. Correlation of miR-155 on formalin-fixed paraffin embedded tissues with invasiveness and prognosis of breast cancer. Zhonghua Wai Ke Za Zhi. 2012;50:1011-4.

123. Kong W, He L, Richards EJ, Challa S, Xu CX, Permuth-Wey J, et al. Upregulation of miRNA-155 promotes tumour angiogenesis by targeting $\mathrm{VHL}$ and is associated with poor prognosis and triple-negative breast cancer. Oncogene. 2014;33:679-89. 
124. Grelier G, Voirin N, Ay A-S, Cox DG, Chabaud S, Treilleux I, et al. Prognostic value of Dicer expression in human breast cancers and association with the mesenchymal phenotype. Br J Cancer. 2009;101:673-83.

125. Khoshnaw SM, Rakha EA, Abdel-Fatah T, Nolan CC, Hodi Z, Macmillan RD, et al. The microRNA maturation regulator Drosha is an independent predictor of outcome in breast cancer patients. Breast Cancer Res Treat. 2013;137:139-53.

126. Leaderer D, Hoffman AE, Zheng T, Fu A, Weidhaas J, Paranjape T, et al. Genetic and epigenetic association studies suggest a role of microRNA biogenesis gene exportin-5 (XPO5) in breast tumorigenesis. Int J Mol Epidemiol Genet. 2011;2:9-18.

127. Sung H, Jeon S, Lee K-M, Han S, Song M, Choi J-Y, et al. Common genetic polymorphisms of microRNA biogenesis pathway genes and breast cancer survival. BMC Cancer. 2012;12:1-12.

128. Lee Y, Ahn C, Han J, Choi H, Kim J, Yim J, et al. The nuclear RNase III Drosha initiates microRNA processing. Nature. 2003;425:415-20.

129. Lund E, Güttinger S, Calado A, Dahlberg JE, Kutay U. Nuclear export of microRNA precursors. Science. 2004;303:95-8.

130. Bernstein E, Caudy AA, Hammond SM, Hannon GJ. Role for a bidentate ribonuclease in the initiation step of RNA interference. Nature. 2001;409:364-6.

131. Chendrimada TP, Gregory Rl, Kumaraswamy E, Norman J, Cooch N, Nishikura K, et al. TRBP recruits the Dicer complex to Ago2 for microRNA processing and gene silencing. Nature. 2005;436:740-4.

132. Kok KH, Ng MH, Ching YP, Jin DY. Human TRBP and PACT directly interact with each other and associate with Dicer to facilitate the production of small interfering RNA. J Biol Chem. 2007;282:17649-57.

133. Schwarz DS, Hutvagner G, Du T, Xu Z, Aronin N, Zamore PD. Asymmetry in the assembly of the RNAi enzyme complex. Cell. 2003;115:199-208. 